\title{
The Effect of Safety Management System Practices, Ethical Leadership and Self-Efficacy on Safety Behaviour of Workers in Hard and Harmful Jobs in Manufactiring Industries of Guilan Province
}

\author{
Mahdi Homayounfar $^{1}$, Mehdi Fadaei Eshkiki ${ }^{*}$, Rouzbeh Sedaghat ${ }^{2}$
}

1. Instructor, Department of Anesthesiology, School of Para-Medicine, Hamadan University of Medical Sciences, Hamadan, Iran

2. MA of Ergonomics, Department of Ergonomics, School of Public Health, Hamadan University of Medical Sciences, Hamadan, Iran

\section{Article Info \\ Original Article \\ Received: $\quad 18$ May 2018 \\ Accepted: $\quad 29$ July 2018 \\ Published Online 29 July 2018}

DOI: 10.30699/jergon.6.1.65

Use your device to scan and read the article online

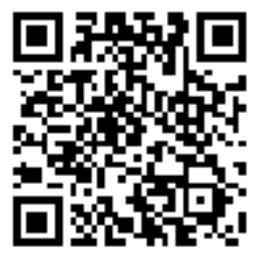

Corresponding Information

Mehdi Fadaei Eshkiki

Assistant Professor of Industria Management, Faculty of Management and Accounting, Rasht Branch, Islamic Azad Univerdity, Rasht, Iran

E-mail: fadaei@iaurasht.ac.ir

\begin{abstract}
Introduction: Safety and safety behaviors are one of the most critical issues ahead manufacturing industries in developing countries, especially in hard and harmful jobs. This research has been conducted to investigate the affecting elements on safety behaviors of workers in hard and harmful jobs in manufacturing industries of Guilan province.
\end{abstract}

Methods: The method of this research is descriptive and its purpose is practical. The statistical population of the research includes workers in hard and harmful jobs in casting and pressing department of manufacturing industries of Guilan province. 384 workers were chosen as sample through non-random sampling and using Morgan table due to the unavailability of the people. Required data were collected using the questionnaire. The questions of safety management system practices are from Chen and Chen, the questions of ethical leadership are from Cheng et al., the questions of self-efficacy are from Schwarzer and Jerusalem and the questions of safety motivation, safety compliance and safety participation are from Neal and Griffin. After the validity (content) and reliability of the questionnaire was confirmed, and the research variables were described using SPSS 21, the hypotheses were tested using structural equation modeling method and based on LISREL 8.5.

Results: Findings verified the effect of safety management system practices on safety compliance and motivation; ethical leadership on safety acceptance and participation; self-efficacy on safety motivation and acceptance; and safety compliance on safety acceptance and participation; however the effect of safety management system practice on safety compliance, self-efficacy on safety participation and ethical leadership on safety acceptance were not. The results indicate that the model variables explains $68.8 \%$ of safety behavior variations.

Conclusions: Self-efficacy has the highest indirect effect on safety behavior (safety acceptance and participation); this happens due to safety motivation. Thus, empowering the self-efficacy will increase safety behaviors.

Keywords: Safety management system practices, Safety behaviour, Safety motivation, Self-Efficacy, Ethical leadership

Copyright (C) 2018, Journal of Ergonomics. This is an open-access article distributed under the terms of the Creative Commons Attribution-noncommercial 4.0 International License which permits copy and redistribute the material just in noncommercial usages, provided the original work is properly cited

How to Cite This Article:

Homayounfar M, Fadaei Eshkiki M, Sedaghat R. The Effect of Safety Management System Practices, Ethical Leadership and Self-Efficacy on Safety Behaviour of Workers in Hard and Harmful Jobs in Manufactiring Industries of Guilan Province. J Ergon. 2018; 6 (1): 65-74 
تأثير اقدامات سيستم مديريت ايمنى، رهبرى اخلاقى و خودكار آمدى بر رفتار رهاى ايمنى

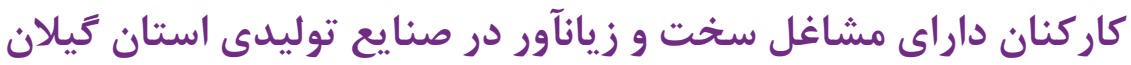

مهدى همايون فر' ، مهدى فدايى اشكيكى "، روزبه صداقت

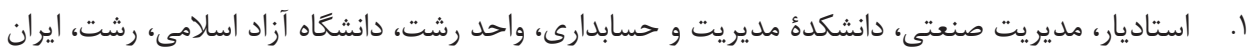

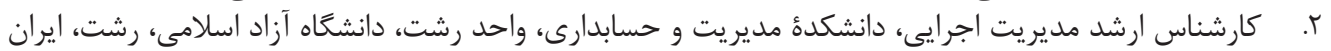

\begin{tabular}{|c|c|}
\hline بده & 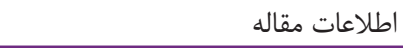 \\
\hline زمينه و هدف: مسئلة رفتارهاى ايمن بهويزه در مشاغل سخت و زيانآور، از اساسىترين موضوعات ييش روى & $\mid r q V / \cdot T / r \Lambda$ \\
\hline صنايع توليدى در كشورهاى درحالتوسعه است. تحقيق حاضر بهدنبال بررسى عناصر اثركذار بر بروز رفتارهاى & 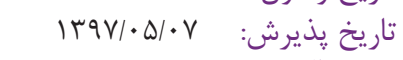 \\
\hline ايمن از سوى كاركنان شاغل در مشاغل سخت و زيانآور صنايع توليدى در استان كَيلان است. & 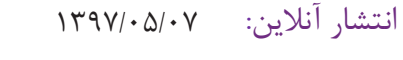 \\
\hline \multicolumn{2}{|l|}{ روشكار: تحقيق حاضر از نظر روش، توصيفى و از نظر هدف، كاربردى است. جامعهُ آمارى تحقيق شامل } \\
\hline كاركنان حوزة مشاغل سخت و زيان آور در بخش ريختهَّى و يرس صنايع توليدى استان كيلان است. بهدليل & 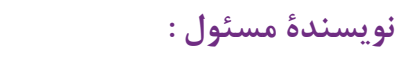 \\
\hline 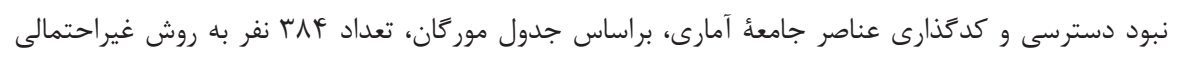 & \multirow{6}{*}{ 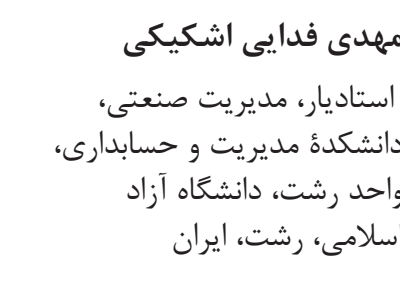 } \\
\hline بلعنوان نمونهٔ آمارى انتخاب شدند و دادههاى لازم با استفاده از يرسشنامه جمعآورى كرديد. سئوالات متغير & \\
\hline اقدامات مديريت سيستم ايمنى بركرفته از تحقيق Chen و،ئوالات متغير رهبرى اخلاقى بركرفته از & \\
\hline تحقيق Cheng و همكاران، سئوالات متغير خودكارآمدى بركرفته از تحقيق Schwarzer و Jerusalem و سئوالات & \\
\hline مربوط به متغيرهاى انََيزه ايمنى، مشاركت ايمنى و يذيرش ايمنى بركرفته از تحقيق Neal و Griffin مىباشد. & \\
\hline ״ֶ از تأييد روايى (محتوى) و پايايى يرسشنامه و توصيف متغيرهاى آن با استفاده از نرمافزار SPSS نسخه آ؟، & \\
\hline فرضيههاى تحقيق براساس روش مدلسازى معادلات ساختارى و نرمافزار ^,ه LISREL آزمون شدند. & \multirow{3}{*}{ aست الكترونيك: } \\
\hline \multicolumn{2}{|l|}{ يافتهها: نتايج نشان مىدهند كه تأثير اقدامات سيستم مديريت ايمنى بر پذيرش و انخَيزء ايمنى، رهبرى } \\
\hline \multicolumn{2}{|l|}{ اخلاقى بر يذيرش و مشاركت ايمنى، خودكار آمدى بر انََيزه و يذيرش ايمنى و انََيزء ايمنى بر يذيرش و مشاركت } \\
\hline ايمنى تأييد شد؛ ولى فرضيات تأثير اقدامات سيستم مديريت ايمنى بر مشاركت ايمنى، خودكارآمدى بر مشاركت & \\
\hline \multirow{2}{*}{\multicolumn{2}{|c|}{ 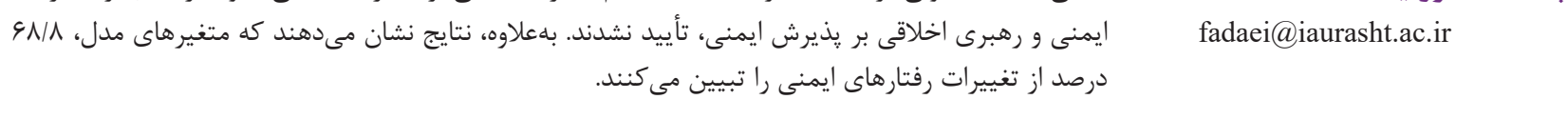 }} \\
\hline & \\
\hline \multicolumn{2}{|l|}{ نتيجهَيرى: خودكارآمدى بيشترين تأثير غيرمستقيم را بر رفتار ايمنى (يذيرش ايمنى و مشاركت ايمنى) } \\
\hline \multicolumn{2}{|l|}{ دارد كه هر دوى اين اثركذارىها بهواسطة انَّيزه ايمنى صورت مى گيرد. بنابراين، تقويت خودكار آمدى موجب } \\
\hline 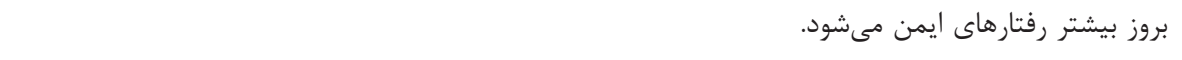 & \\
\hline وازههاى كليدى: اقدامات سيستم مديريت ايمنى، رفتار ايمنى، انخيزءٔ ايمنى، خ & \\
\hline
\end{tabular}

افزايش روزافزون تعداد و تنوع حوادث شغلى است. براساس

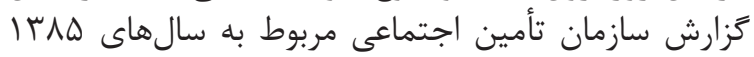

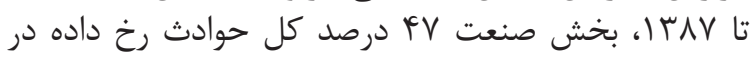

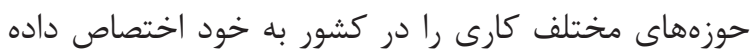

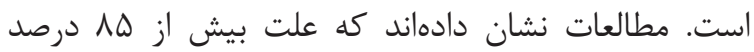

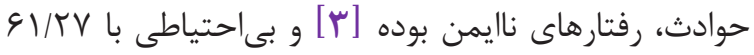

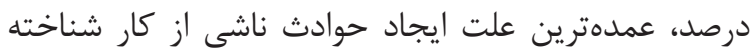

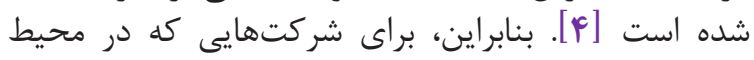

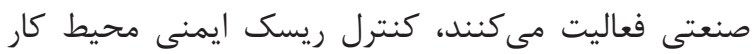

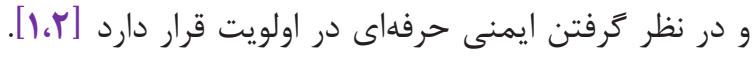
در بررسى هاينريج و عرضأ مدل دومينو، انسان بهعنوان

\section{مقدمه}

حفظ سلامت و ايمنى نيروى انسانى از ضرورتهاى مناى

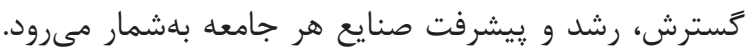

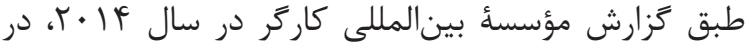

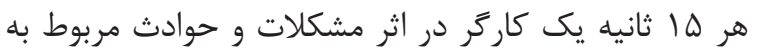

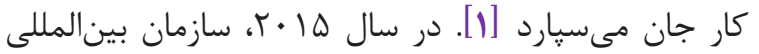

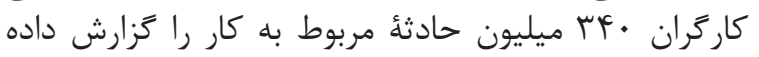

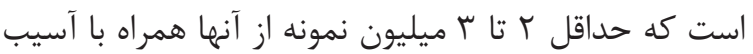

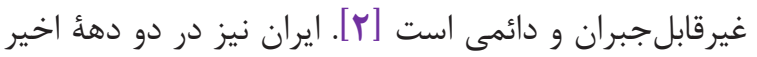

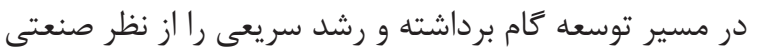

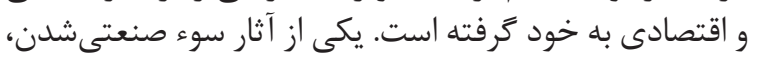




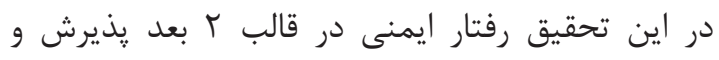

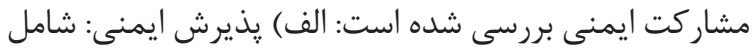

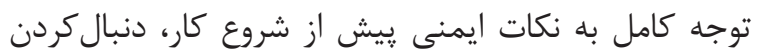

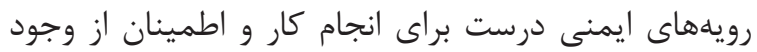

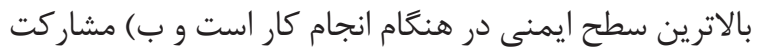

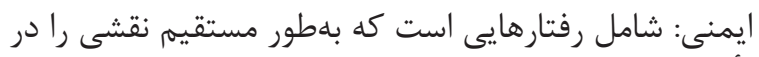

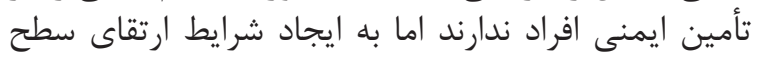

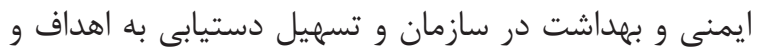

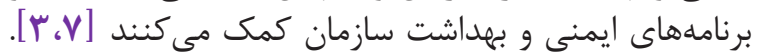
عوامل مختلفى بر رفتار ايمنى در سازمان مؤثرندا:

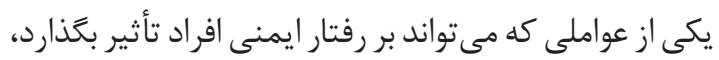

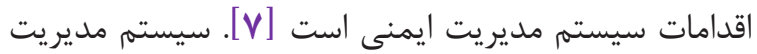

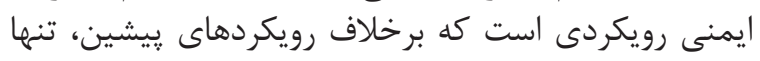

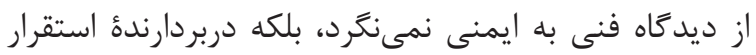

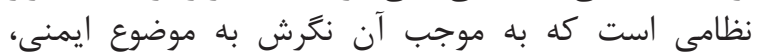

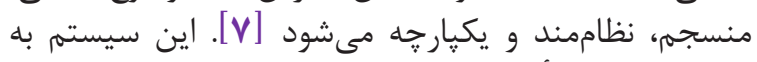

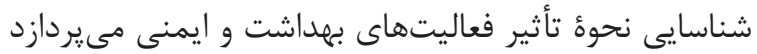

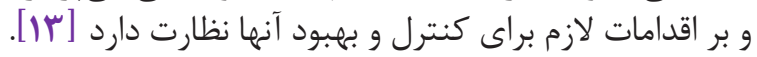

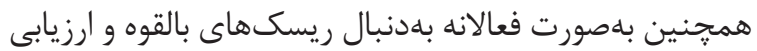

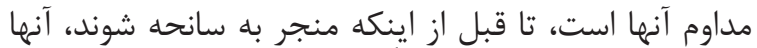

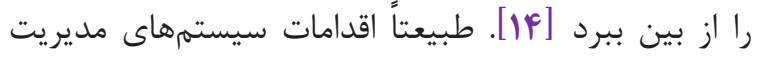

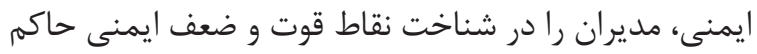

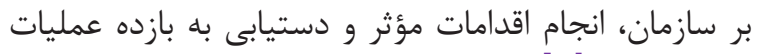

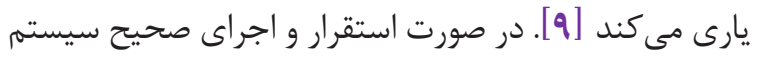

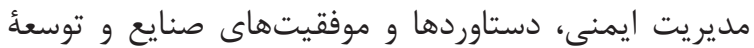

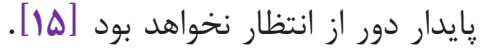

عامل ديخر مؤثر بر بروز رفتارهاى ايمن سازمان، رهبرى

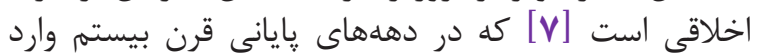

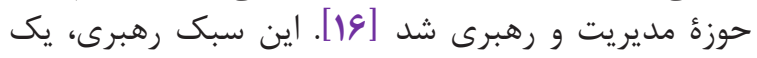

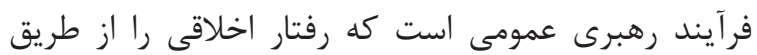

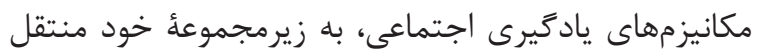

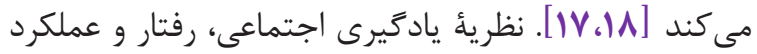

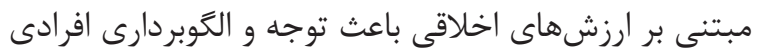

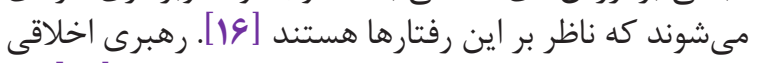

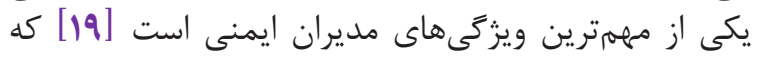

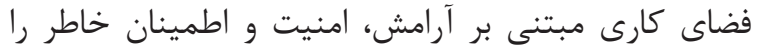

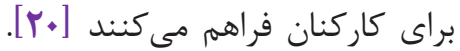

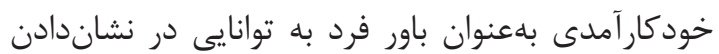

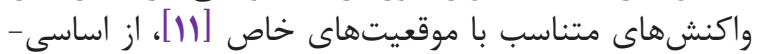

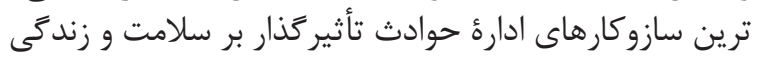

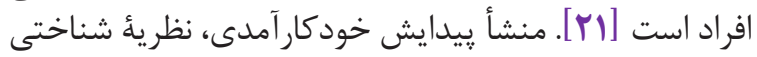

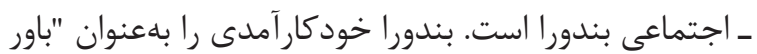

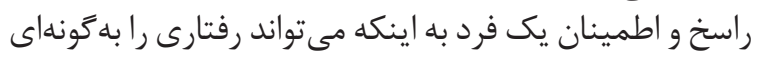

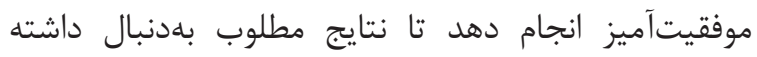

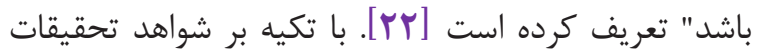

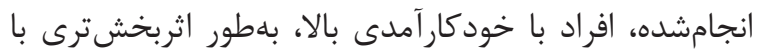

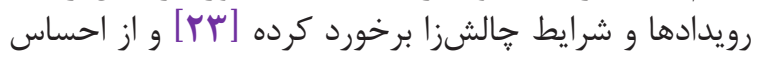

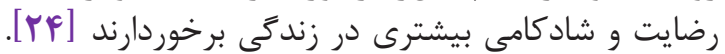

مهمترين عامل بروز حوادث حرفهاى شناخته شد. هاينريج

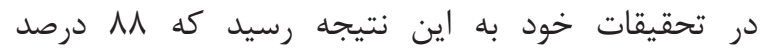

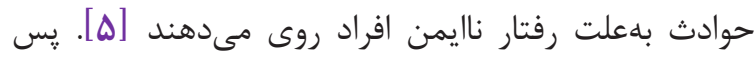

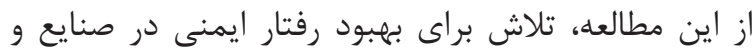

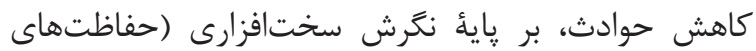

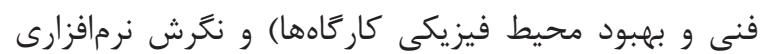

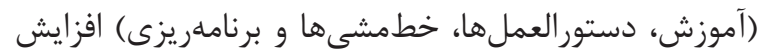

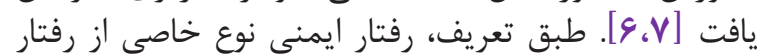

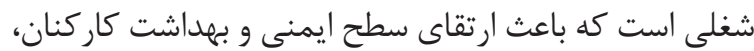

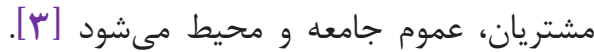

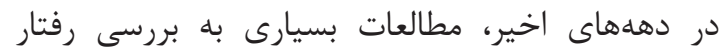

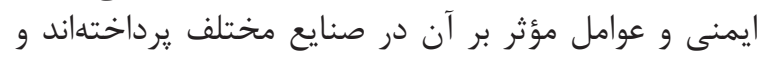

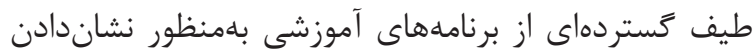

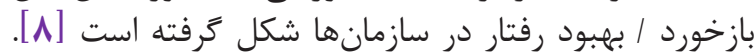

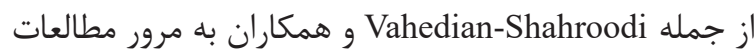

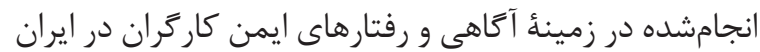

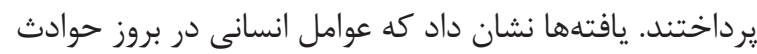

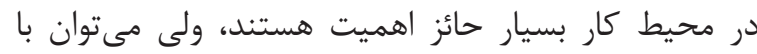

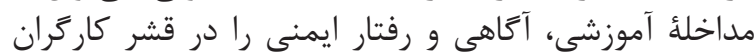

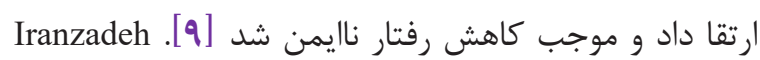

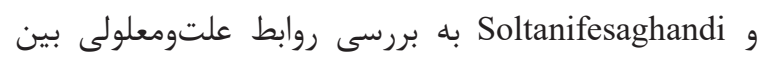
عوامل سازمانى مؤثر بر عملكرد ايمنى صنايع با با استفاده از براز

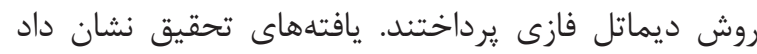

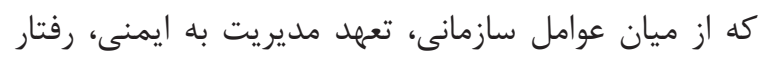

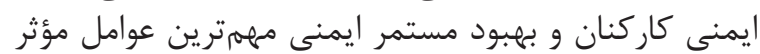

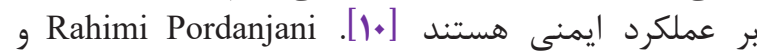
Mohamadzade Ebrahimi

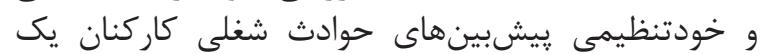

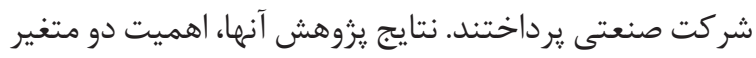

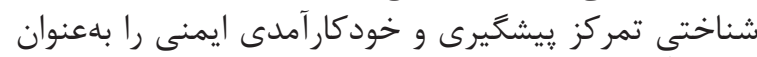

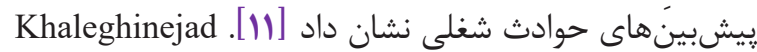

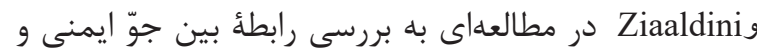

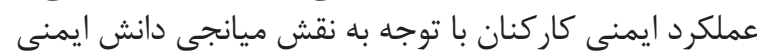

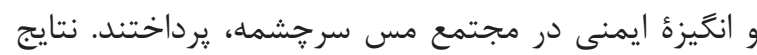

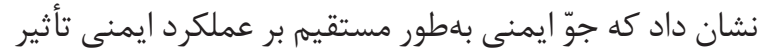

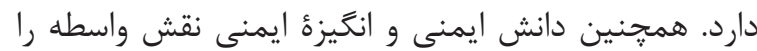

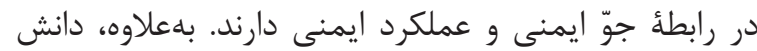

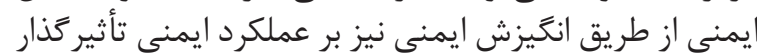

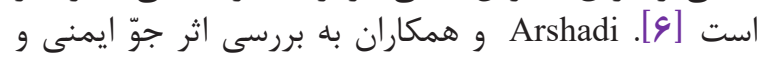

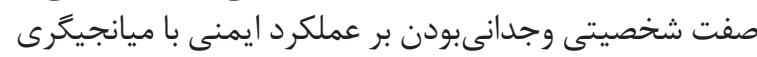

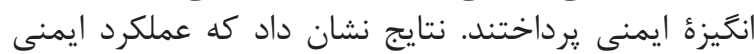

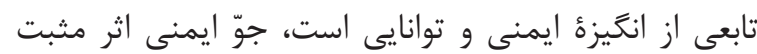

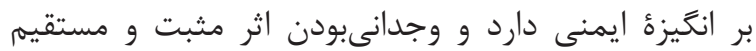

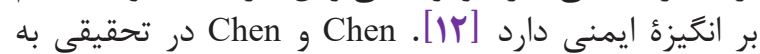

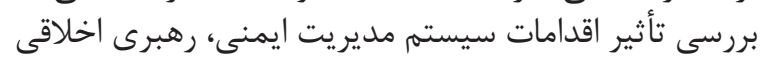

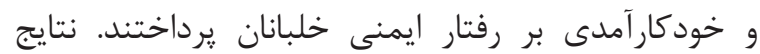

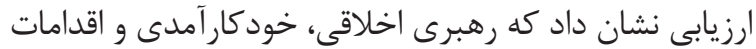

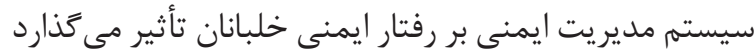

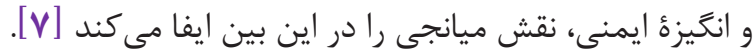


مشاغل سخت و زيان آور طبق تعريف شامل كارهايى هستند

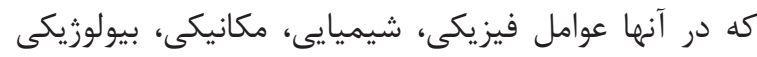

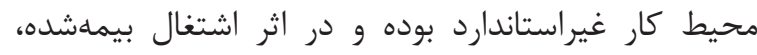

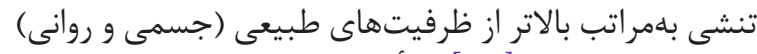

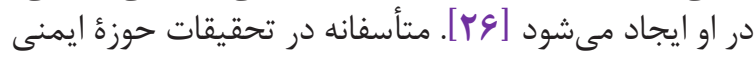

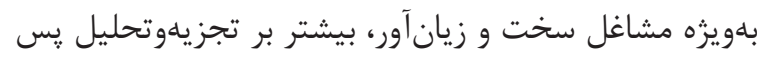

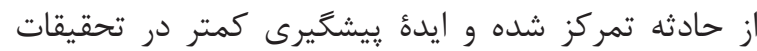

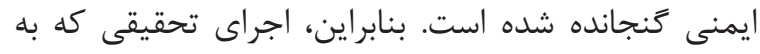

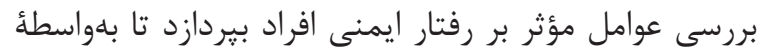

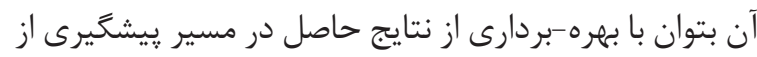

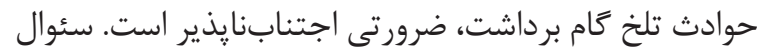

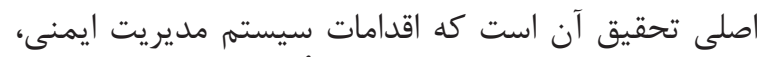

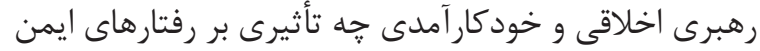

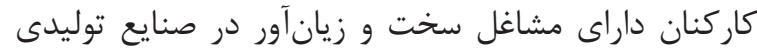

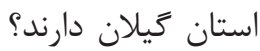

با توجه به مفاهيم نظرى بيانشده در مقدمأ تحقيق و

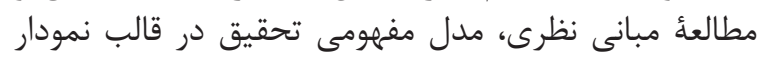

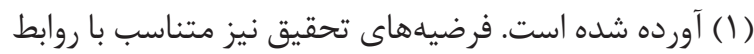
مدل تحقيق، تعريف شدهاند كه در جدول (I) أَ) آورده شدهاند.

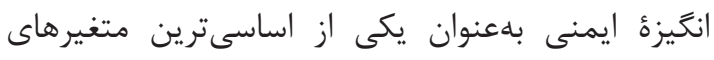

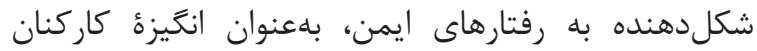

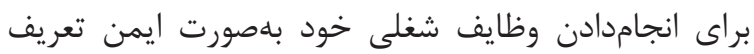

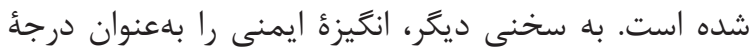

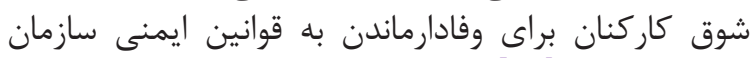

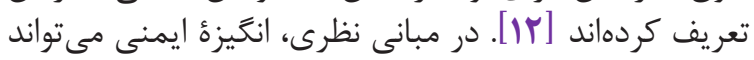

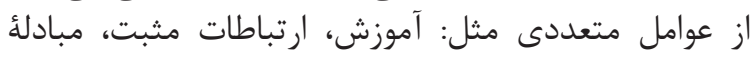

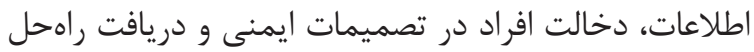

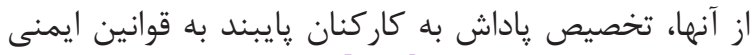

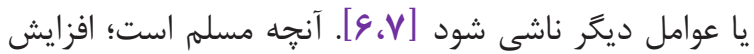

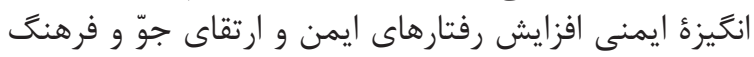

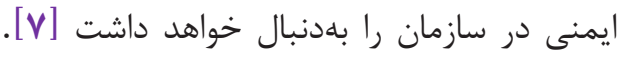

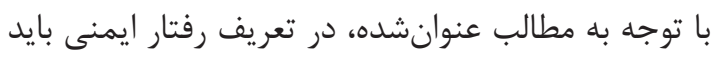

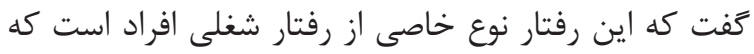

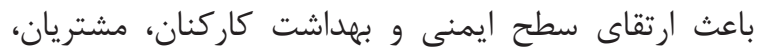

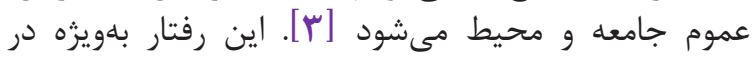

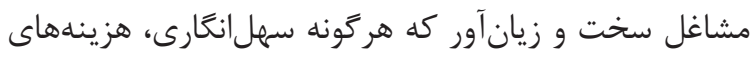

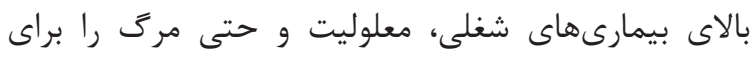

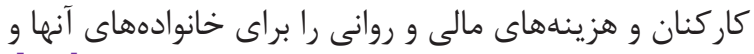

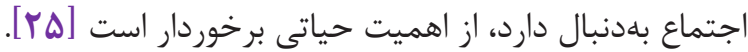

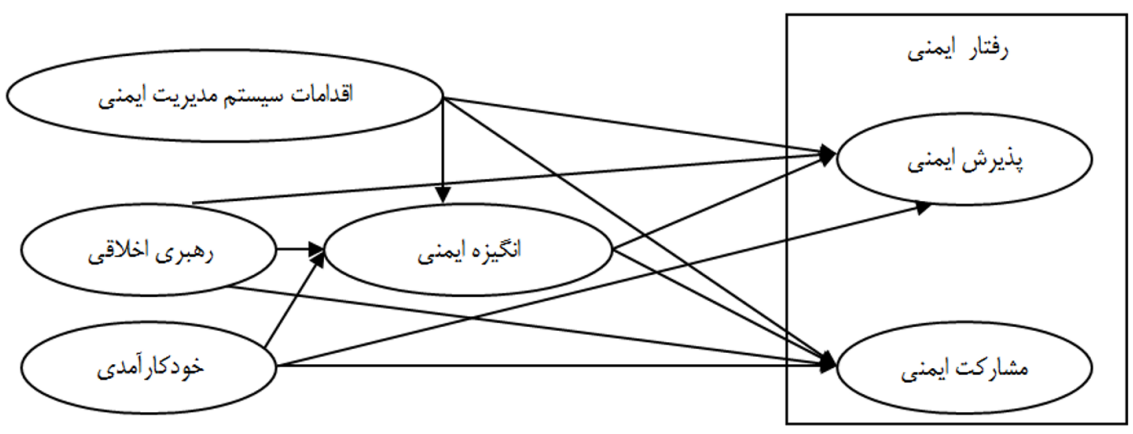

نمودار 1. مدل مفهومى تحقيق

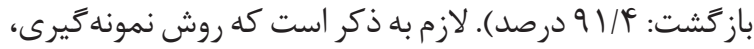

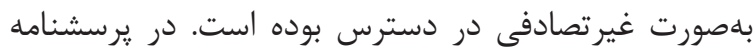

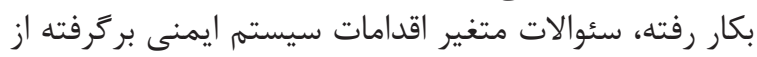

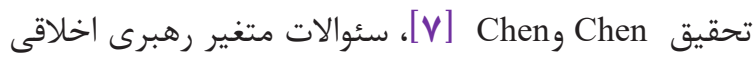

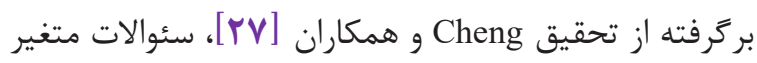

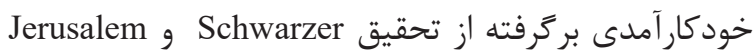

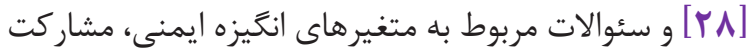

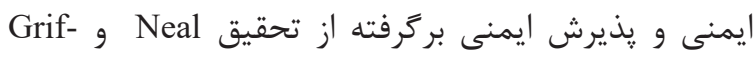
[rq fin

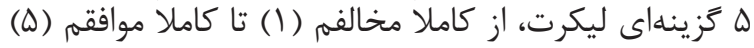

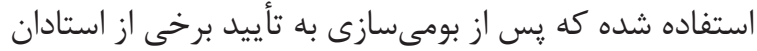

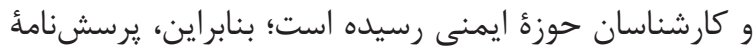

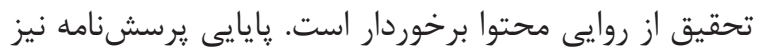

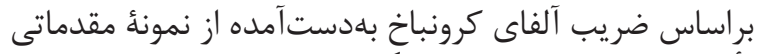

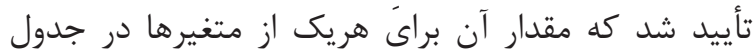

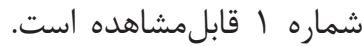

\section{مواد و روشها}

تحقيق حاضر به روش توصيفى و با هدف كارد اربردي

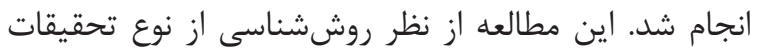

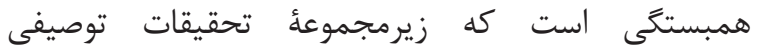

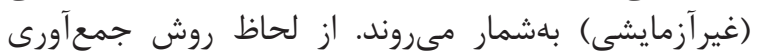

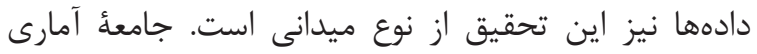

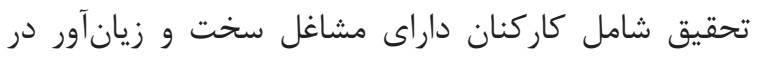

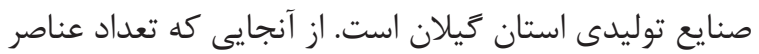

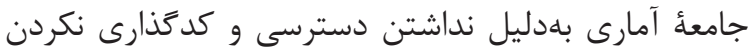

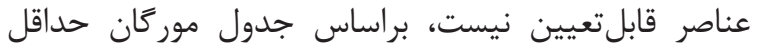

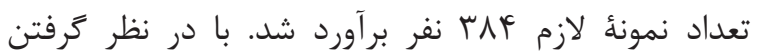

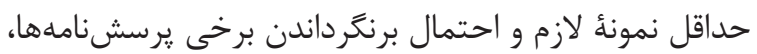

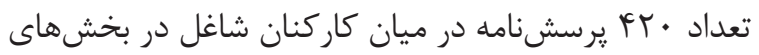

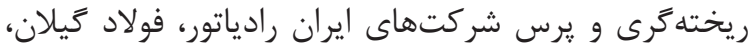

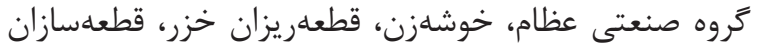

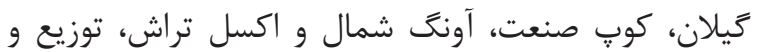

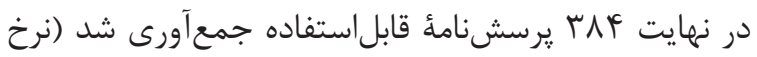


آن با استفاده از نرمافزار SPSS، فرضيههاى تحقيق براساس

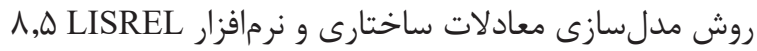

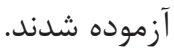

براساس نتايج حاصل از جدول فوق، مىتوان عنوان كرد

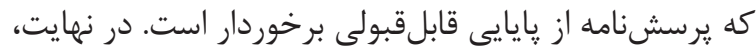

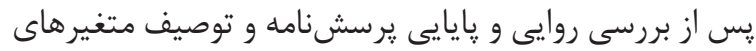

جدول ا. ضريب آلفاى كرونباخ

\begin{tabular}{|c|c|c|c|}
\hline نتيجه & مقدار آلفا & كويه & متغير \\
\hline ت ت تأييد & $\cdot|A T|$ & $r \cdot$ & اقدامات سيستم مديريت ايمنى \\
\hline تأييد & $\cdot \mid \wedge \Delta \varphi$ & $\Delta$ & ر إبرى اخلاقى \\
\hline تأييد & $\cdot / \vee \wedge 9$ & 9 & خود كارآ آمدى \\
\hline تأييد & $\cdot|\lambda| t$ & r & انخيزهٔ ايمنى \\
\hline ت تأييد & . IATt & r & يذيرش ايمنى \\
\hline 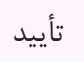 & - IAৎ9 & r & مشاركت ايمنى \\
\hline
\end{tabular}

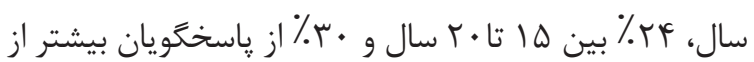

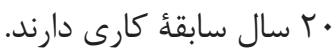

\section{توصيف متغيرهاى تحقيق}

״يش از آزمون مدل و فرضيههاى تحقيق، متغيرهاى مدل در قالب جدول (r) بررسى شدند.

مطابق جدول فوق، بيشترين و و كمترين ميانگين بهترتيب مربوط به متغيرهاى اقدامات سيستم مديريت فئرين

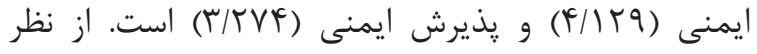

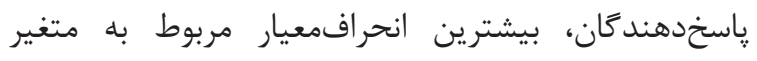

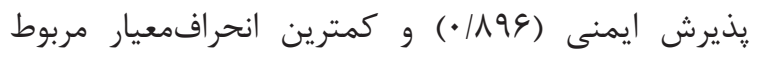

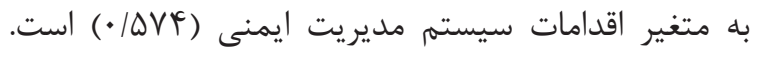

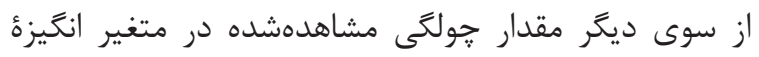

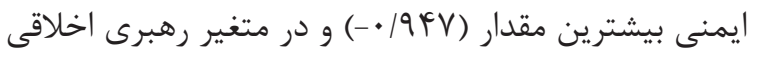

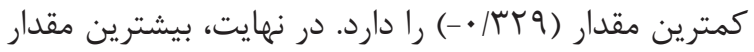

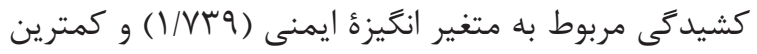

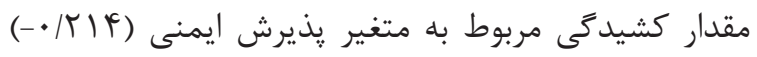

\section{بافتهها}

بامنظور تحليل دادههاى تحقيق، ابتدا متغيرها در قالب

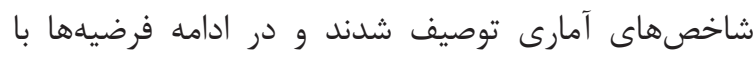
استفاده از روش مدل هازى امع معادلات ساختارى آزمايش شدند:

\section{توصيف متغيرهاى جمعيتشناختى}

- توصيف سن ياسخدهندگًان: با توجه به يافتهها،

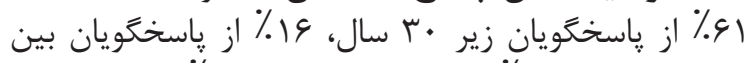

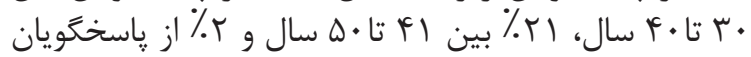
بيشتر از • له سال سن دارند.

- توصيف ميزان تحصيلات ياسخدهندًان: با توجه

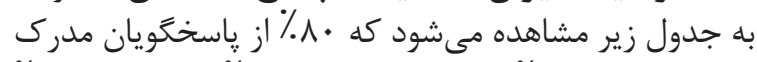

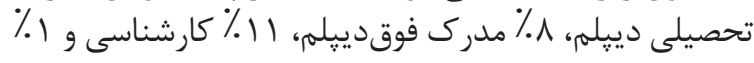
مدرك كارشناسى ارشد دارند.

- توصيف سابقة خدمت در سازمان گِاسخدهند

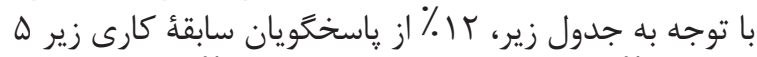

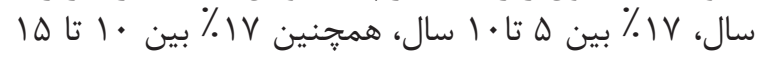

جدول r. توصيف آمارى متغيرهاى مدل

\begin{tabular}{|c|c|c|c|c|c|c|c|}
\hline كشيدَّى & جوللىى & انحراف معيار & ميانگين & بيشترين & كمترين & تعداد & متغير \\
\hline$\cdot / \wedge \Delta$ & $-\cdot 1019$ & $\cdot \mid \Delta V F$ & $r / l r q$ & $\Delta$ & $1 / 0$ & rAf & مديريت ايمنىى سيستم \\
\hline . MTY & $-\cdot / r r q$ & $\cdot \mid \Delta \Lambda \Lambda$ & $r / 9 \cdot \Delta$ & $\Delta$ & $1 / \Delta$ & rAF & رهبرى اخلاقى \\
\hline.$- / 1 \mathrm{VV}$ & $-\cdot / F V F$ & $\cdot / V V r$ & r/FYA & $\Delta$ & 1 & rAF & خود كارآمدى \\
\hline $1 / v r q$ &.$- / 9 F V$ & .1994 & $F / \cdot \Delta f$ & $\Delta$ & 1 & rak & انخَيزة ايمنى \\
\hline$-\cdot / r \mid F$ & זrז/•- & $\cdot 1199$ & $r / T V F$ & $\Delta$ & 1 & rAF & يذيرش ايمنى \\
\hline$\cdot / 9 \Delta \Delta$ & $-\cdot / V \cdot 9$ &.$/ 219$ & r/ANF & $\Delta$ & $1 / \pi \Delta$ & rar & مشاركت ايمنى \\
\hline
\end{tabular}




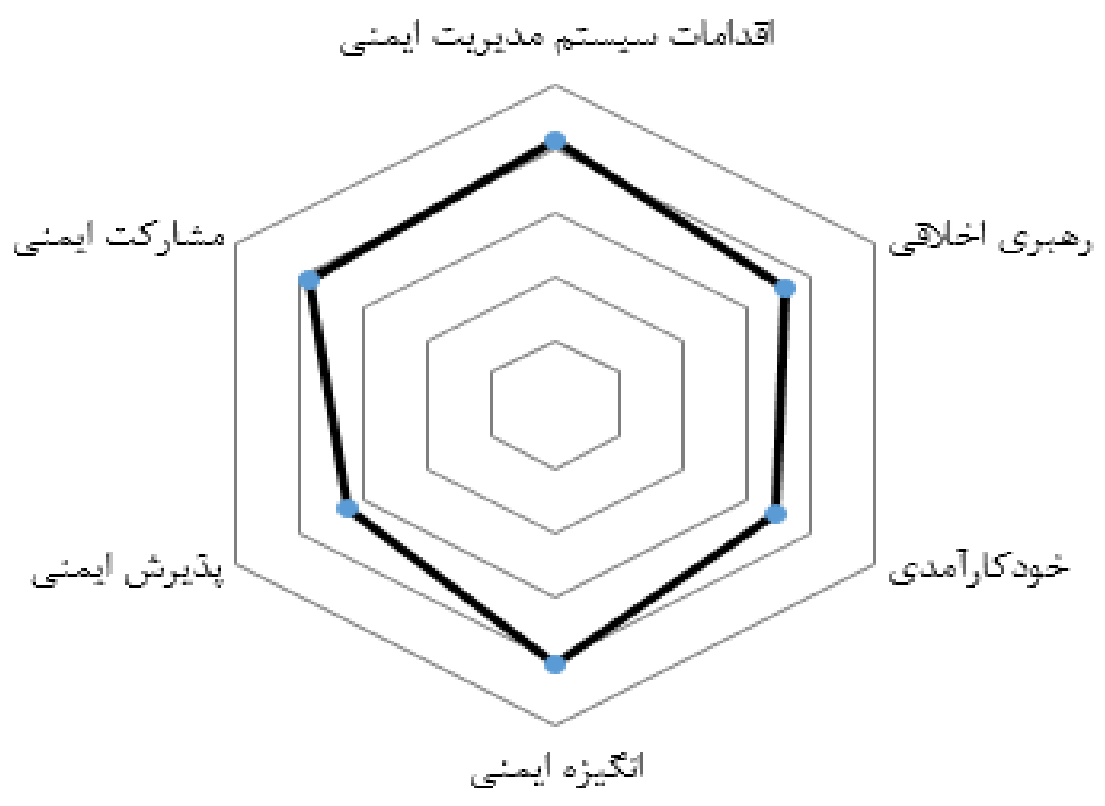

نمودار r. نمودار رادارى ميانغين متغيرهاى تحقيق

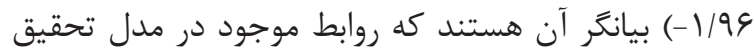

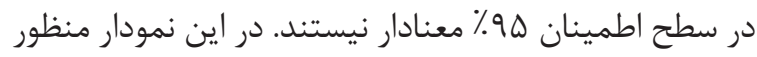

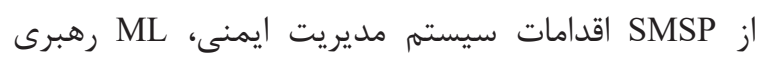

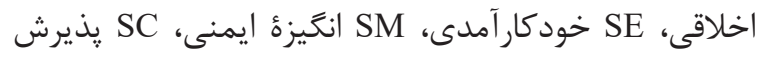
ايمنى و SP مشاركت ايمنى است.

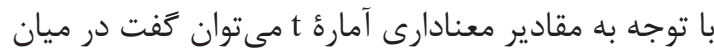

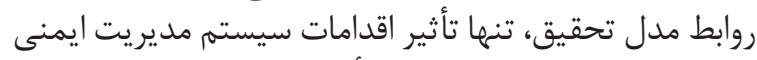

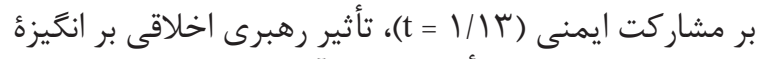

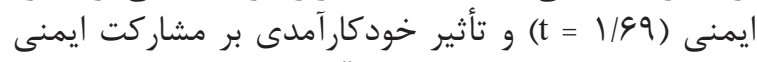

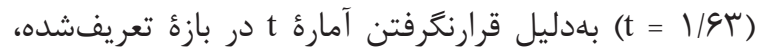

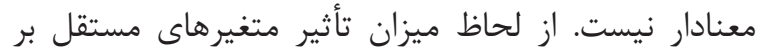

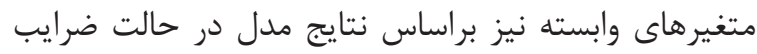

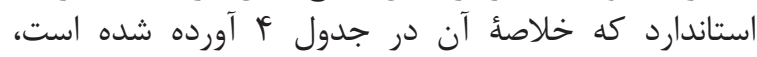

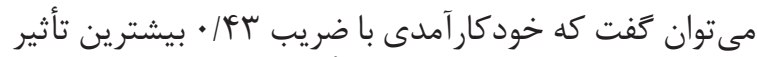

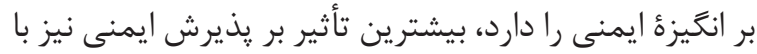

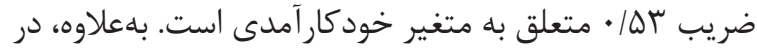

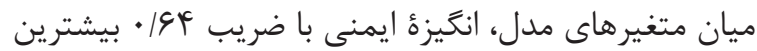

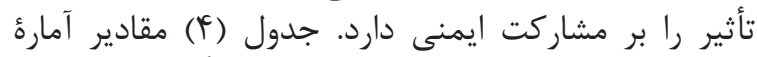

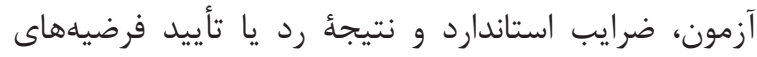

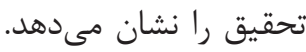

\section{آزمون نرماليتهُ متغيرها و برازش مدل}

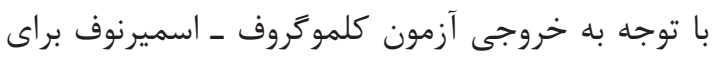

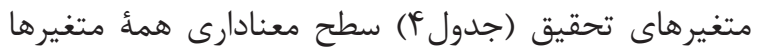

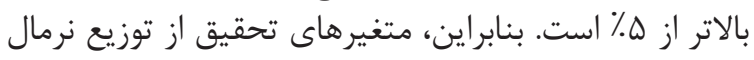

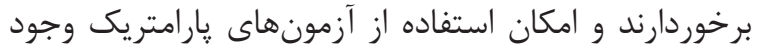

يس از بررسى توزيع متغيرهاى مدل تحقيق، براساس

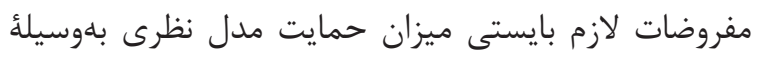

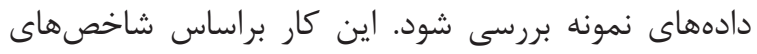
برازش و معنى دارى مدل صورت مى كيرد.

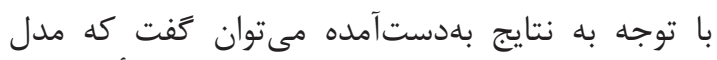
تحقيق از نظر شاخصهاى معنىدارى و برازش تأن تأييد شده

\section{آزمون فرضيه آن تحقيق}

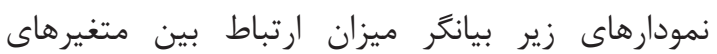

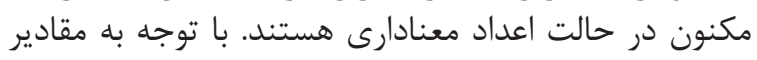

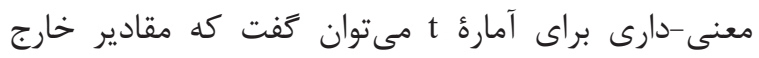

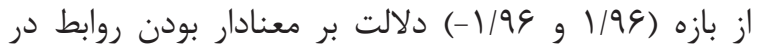

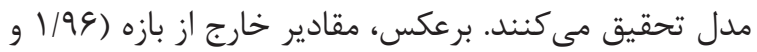

جدول r. شاخصهاى برازش مدل

\begin{tabular}{|c|c|c|c|c|c|c|}
\hline IFI & CFI & NFI & NNFI & GFI & $\mathrm{x}^{2} / \mathrm{df}$ & RMSEA \\
\hline$>.19$ & $>\cdot 19$ & $>\cdot 19$ & $>\cdot 19$ & $>\cdot 19$ & $\leq r$ & $\leq \cdot 1 \cdot 1$ \\
\hline.$/ 97$ &.$/ 9 V$ &.$/ 9 \Delta$ &.$/ 98$ & .191 & $r / 1 \Lambda$ & .1 .91 \\
\hline
\end{tabular}




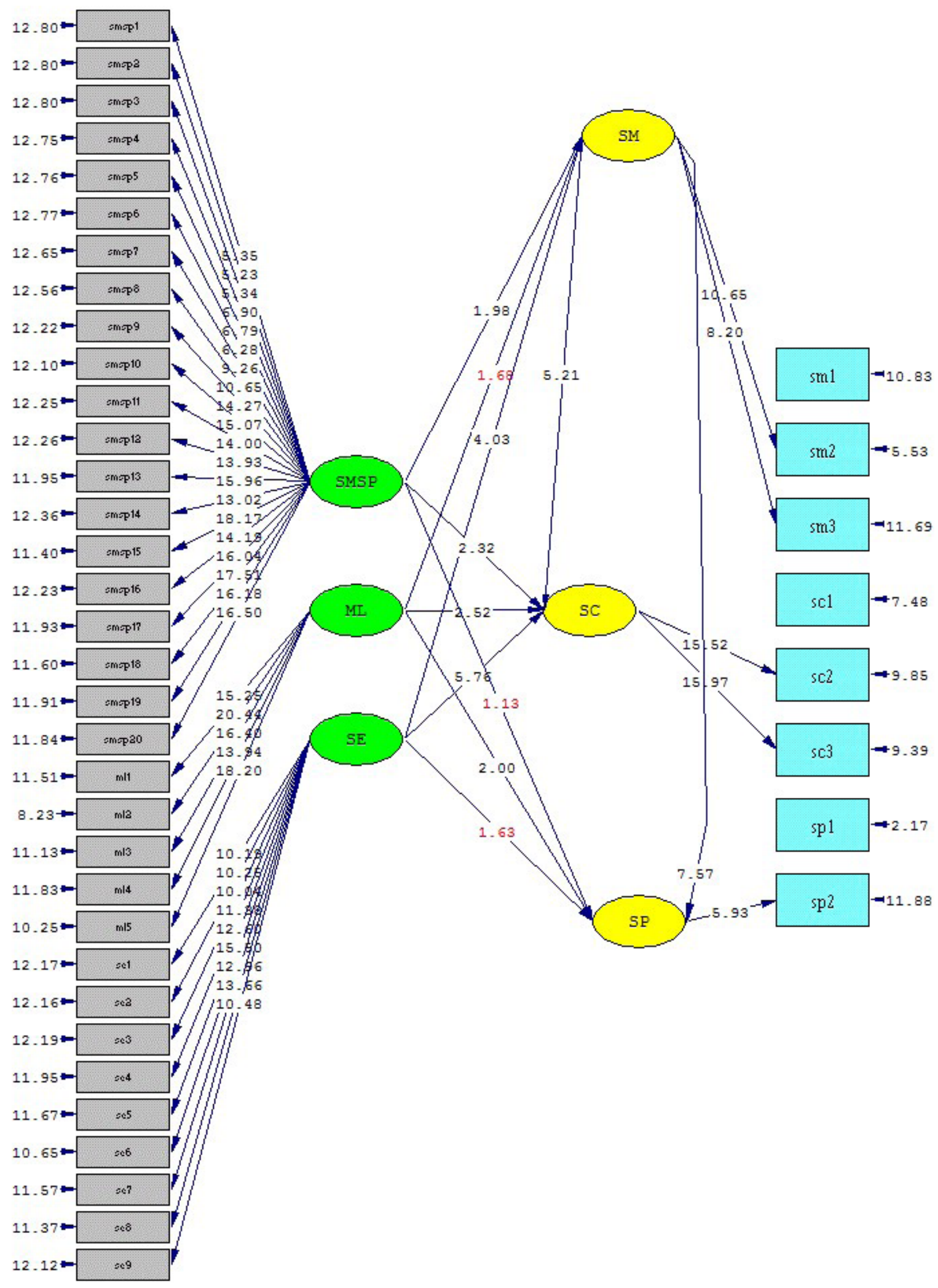

Chi-Square=2594.52, df=1188, P-value=0.00000, RMSEA=0.061 
جدول F. نتايج آزمون فرضيات تحقيق

\begin{tabular}{|c|c|c|c|c|}
\hline نتيجهَكيرى & ضريب & آمارهء آزمون & فرضيه & شماره \\
\hline تأييد & $\cdot / 48$ & $t / 4 T^{2}$ & اقدامات سيستم مديريت ايمنى بر يذيرش ايمنى تأثير گذار است. & 1 \\
\hline تأييد & - & $1 / 14$ & اقدامات سيستم مديريت ايمنى بر مشاركت ايمنى تأثيركذار است. & r \\
\hline تأييد & $\cdot / 48$ & $1 / 91$ & اقدامات سيستم مديريت ايمنى بر انخيزهٔ ايمنى تأثيركذار است. & r \\
\hline تأييد & $\cdot / r$ & T/QT & رهبرى اخلاقى بر پذيرش ايمنى تأثيركذار است. & r \\
\hline تأييد & $\cdot \pi \cdot$ & $r / \cdot$ & رهبرى اخلاقى بر مشاركت ايمنى تأثير گذار است. & $\Delta$ \\
\hline تأييد & - & $1 / 99$ & رهبرى اخلاقى بر انخَيزء ايمنى تأثيركذار است. & 4 \\
\hline تأييد & $\cdot \mid \Delta r$ & $\Delta / V \varphi$ & خودكار آمدى بر يذيرش ايمنى تأثير كذار است & v \\
\hline تأييد & - & $1 / 94$ & خودكارآمدى بر مشاركت ايمنى تأثير كذار است. & $\wedge$ \\
\hline تأييد & $\cdot \operatorname{cr}$ & F/Tr & خود كارآمدى بر انخيزة ايمنى تأثير كذار است. & 9 \\
\hline تأييد & $\cdot 148$ & $\Delta / T_{1}$ & انخيزهُ ايمنى بر پذيرش ايمنى تاثيركذار است & 1. \\
\hline تأييد & $\cdot \mid 94$ & $V / \Delta V$ & انخيزة ايمنى بر مشاركت ايمنى تأثيركذار است. & 11 \\
\hline
\end{tabular}

خودكارآمدى از طريق انخيزه ايمنى است، باهعلاوه بيشترين

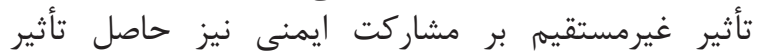
خودكارآمدى از طريق انتيزه ايمنى است.
در ادامه، جدول (ه) نيز به بررسى مسيرهاى غيرمستقيمم (همان

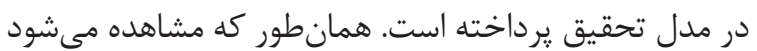
بيشترين تأثير غيرمستقيىم بر يذيرش ايمنى، حاصل هاصل تأثير

جدول ه. تحليل مسيرهاى غيرمستقيم مدل تحقيق

\begin{tabular}{|c|c|}
\hline تأثير غير مستقيم & مسير \\
\hline$\cdot 1 \cdot 949=\cdot / 49 \times \cdot / 49$ & 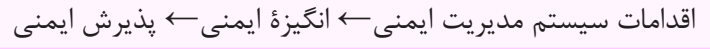 \\
\hline$\cdot / 1994=\cdot 194 \times \cdot / 49$ & اقدامات سيستم مديريت ايمنى ـ انگَيزء ايمنى ـ مشاركت ايمنى \\
\hline$\cdot=\cdot / \pi \xi \times \cdot$ & رهبرى اخلاقى ـ انخَيزه ايمنى ؟ يذيرش ايمنى \\
\hline$\cdot=\cdot|q| \times \cdot$ & رهبرى اخلاقى ـ انخَيزه ايمنى ؟ مشاركت ايمنى \\
\hline$\cdot / 1 D F \Lambda=\cdot / \mu G \times \cdot / 4 T$ & خودكارآمدى ـ انخيزه ايمنى ـ ذِيرش ايمنى \\
\hline$\cdot / T V D T=\cdot / 9 F \times \cdot / 4 T$ & خود كار آمدى ـ انكَيزء ايمنى ـ مشاركت ايمنى \\
\hline
\end{tabular}

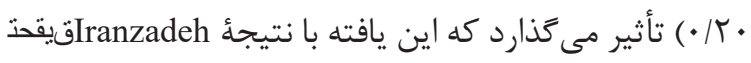

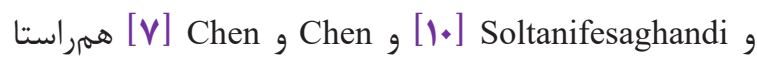
است. معنادار بودن تأثير متغير خودكارآمدى بر يذيرش

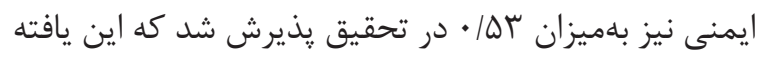
با نتيجة تحقيق Rahimi و Mohamadzade [V] Chen با توجه به مدل تحقيق، مشاهده مىشود كه ميزان آماره

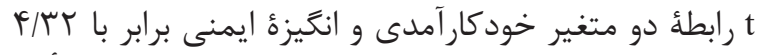

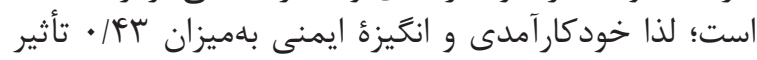

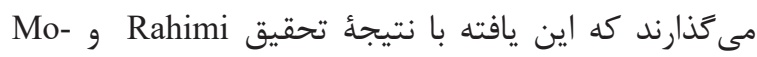
ن hamadzade نتايج جدول (أ) نيز نشان مىدهند كه رابطة دو متغير انخيزه

\section{بحث و نتيجه گيرى}

با توجه به نتايج، اقدامات سيستمم مديريت ايمنى بر يذيرش

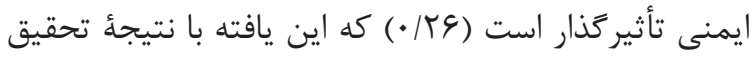

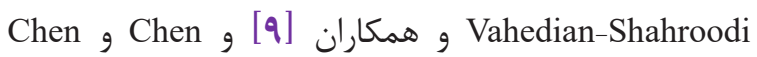
همراستا است. با توجه به مدل تحقيق در حالت اعداد

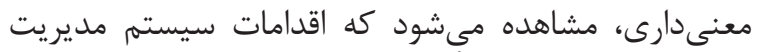

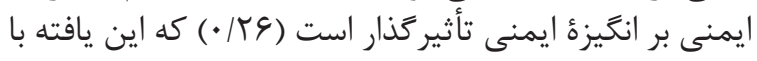

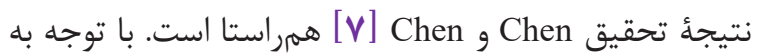

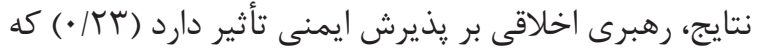

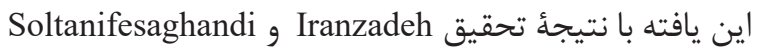

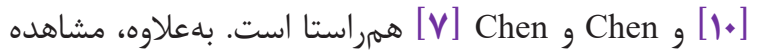
مىشود كه رهبرى اخلاقى نيز بر مشاركت ايمنى (بهميزان 
مسيرهاى غيرمستقيم در مدل تحقيق مشخص شد كه كه

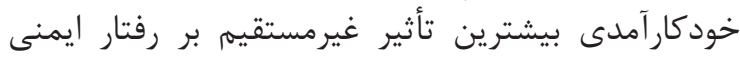

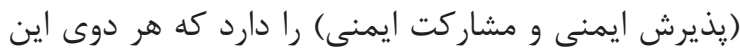

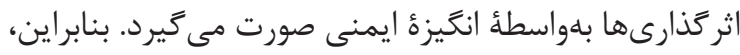

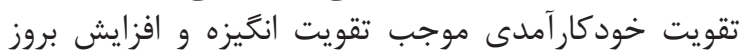

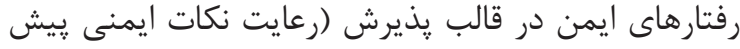

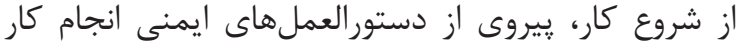

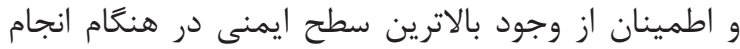

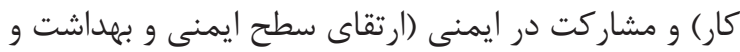

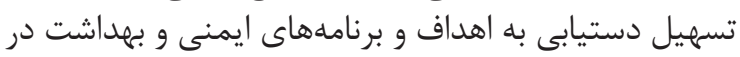

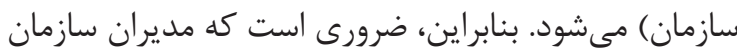

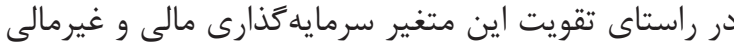
مناسبى انجام دهند. سياسگز ارى

از همكارى مديران شركتهاى ايران رادياتور، فولاد

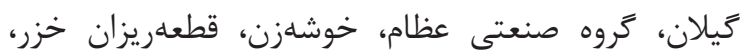

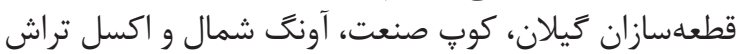
در فرايند جمعآورى دادههاى تحقيق، كمال صنال تشكر را داريم.

$$
\text { تعارض منافع }
$$

بين نويسندَان هيج گَونه تعارضى در منافع وجود ندارد.

\section{References}

1. Shackleton R. An Examination of Different Measures of Work Experience, and the Relationship between Previous Experience and Safety [dissertation]. Christchurch New Zealand: University of Canterbury; 2016.

2. Bouten L, Hoozée S. Let's do it safely: How Altrad Balliauw configured a package of control systems. J Clean Prod. 2016;136:172-80. https:// doi.org/10.1016/j.jclepro.2016.01.105

3. Mahdinia M, Arsanqjang S, Sadeghi A, Malakouti J, Karimi A. Development and validation of a questionnaire for safety behavior assessment. Iran Occup Health. 2016;13(2):92-102. http:// ioh.iums.ac.ir/article-1-1504-en.html

4. tamin.ir [homepage on the Internt]. Tehran: Social Security Organization. 2016 Jun 15; Available from: http://www.tamin.ir/News/ Item/28301/16/28301.html.

5. Heinrich HW. Industrial accident prevention: a scientific approach. New York: McGraw-Hill; 1931.

6. Khaleghinejad A, Ziaaldini M. Relationship between employees' safety climate and safety performance with respect to mediating effect of safety knowledge and safety motivation in Sarcheshmeh copper complex. Health and Safety at Work. 2015;5(4):69-86. http://jhsw.tums.ac.ir/

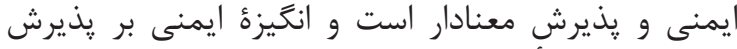

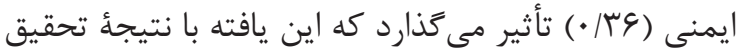

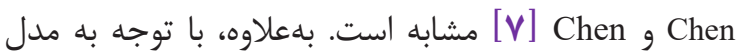

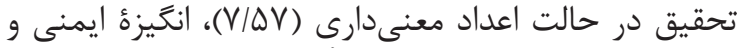

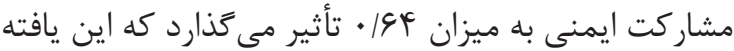

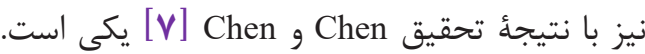

با توجه به نتايج، اثرگذارى متغير اقدامات سيستم

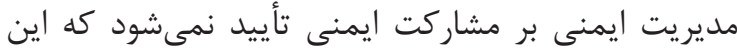

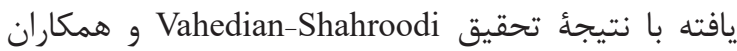

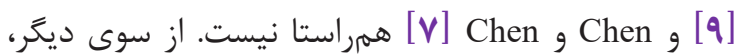

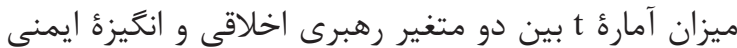

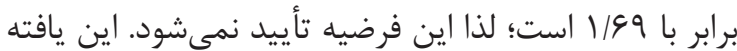

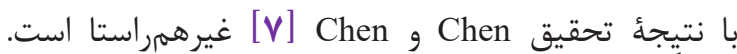

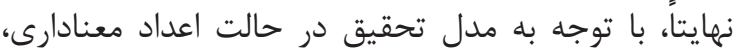

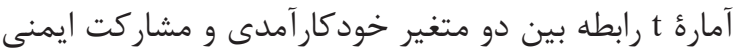

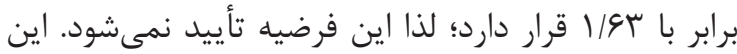

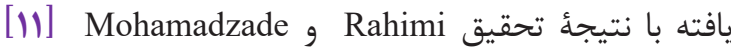

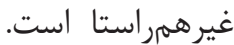

باتوجه به نتايج حاصل از فرضيههاى تحقيق و بررسى

article-1-5332-en.html

7. Chen CF, Chen SC. Measuring the effects of Safety Management System practices, morality leadership and self-efficacy on pilots' safety behaviors: Safety motivation as a mediator. Safety Science. 2014;62:376-85. https://doi. org/10.1016/j.ssci.2013.09.013

8. Navidi MM. Behavioural safety in work environment. Andisheh Gostar-e Saipa, 2012;126:76-7.

9. Vahedian-Shahroodi M, Mohammadi F, Tehrani $\mathrm{H}$. A review of studies in the field of knowledge and safe behaviors of workers in Iran. J Health Lit. 2016;1(1):25-38. http://literacy.ihepsa.ir/article-1-24-en.html

10. Iranzadeh S, Soltanifesaghandi G. Measuring Cause and Effect Relations among the Organizational Factors Affecting the Performance of Industry Safety Based on Fuzzy DEMATEL Method. Iran Occup Health. 2016;13(1):27-37. http:// ioh.iums.ac.ir/article-1-1257-en.html

11. Rahimi Pordanjani T, Mohamadzade Ebrahimi A. Self-efficacy and self-regulation predicted employee's occupational accidents in an industrial company. Occupational Medicine. 2016;7(3):110. http://tkj.ssu.ac.ir/article-1-505-en.html

12. Arshadi N, Ahmadi E, Etemadi A. The effect of the safety climate and conscientiousness on the safety performance with mediating role of moti- 
vation. Journal of Psychology Models and Methods. 2011;2(5):101-16. $\quad$ http://www.sid.ir/en/ journal/ViewPaper.aspx?ID=306163

13. Rezaei R, Jamshidi N. Study of safety behavior against workplace harmful factors in Township of Zanjan. Journal of Health Promotion Management. 2015;4(4):14-21. http://jhpm.ir/article-1506-en.html

14. Elyasi M, Karimi Govarashki MH, Saedi Basmanj AR. Key success factors and bottlenecks of the safety management system in airlines companies. Journal of Standarization Management and Quality. 2012;2(4):58-69.

15. Behrouz MS, Hamedani A. The role of safety management system, health and environment in improving industrial processes and reducing the accidents. Way of Health, Safety and Environment. 2014;3(3):9-15.

16. Taghizadeh H, Sltani Fasghandis GR. The Role of Identification \& Ethical Beliefs of Employees at Functional Results of Ethical Leadership. Ethics in Science and Technology. 2016;10(4):97106. http://ethicsjournal.ir/article-1-182-en.html

17. Babalola MT, Stouten J, Euwema MC, Ovadje F. The Relation Between Ethical Leadership and Workplace Conflicts The Mediating Role of Employee Resolution Efficacy. Journal of Management. 2016;44(5):2037-63. https://doi. org/10.1177/0149206316638163

18. Chen ASY, Hou YH. The effects of ethical leadership, voice behavior and climates for innovation on creativity: A moderated mediation examination. The Leadership Quarterly. 2016;27(1):1-13. https://doi.org/10.1016/j.leaqua.2015.10.007

19. Mir Kamali SMA, Karami MR. Study of Relation between Ethic Leadership Perception of Managers and Personnel Performance. Journal of Development Evaluation Management. 2016;24:1122. http://www.jdem.ir/article 501 en.html

20. Khalaveh E, Mahdad A. Predicting of Perceived Job Security \& Organizational Trust through Ethical Leadership \& Adherence to Psychological Contract. Ethics in Science and Technology. 2016;10(4):37-44. http://ethicsjournal.ir/article1-176-en.html
21. Ghaed Rahmati M, Asadi M, Shir-Alipour A. A comparison between male and female students in self-efficacy meta-analysis. Journal of Instruction and Evolution. 2013;6(22):87-97. http:// jinev.iaut.ac.ir/article_521541_en.html

22. Ebrahimi H, Khamesan A, Pakdaman M. Construction and Validation of Smoking Abstinence Self - Efficacy Scale. Journal of Applied Psychological Research. 2014;5(3):95-110. http://www. sid.ir/En/Journal/ViewPaper.aspx?ID=421010

23. Mirmohamad Ali M, bahiraee A, Rahimi A, Hashemzadeh M, Sohrabi N, Sohrabi Z. Effect of educational package on breastfeeding self-efficacy in postpartum period. Payesh. 2014;13(2):221-8. http://www.payeshjournal.ir/En/article/Article. aspx?aid $=109922 \&$ tabid $=$

24. Saffari M, Sanaeinasab H, Rashidi Jahan H, Purtaghi GH, Pakpour A. Happiness, Self-efficacy and Academic Achievement among Students of Baqiyatallah University of Medical Sciences. J Med Educ Dev. 2014;7(13):45-56. http://zums. ac.ir/edujournal/article-1-185-en.html

25. Mohammadi Zeydi I, Heydarnia AR, Niknami SA. Safety climate measurement at workplace: development, validity and reliability. Payesh. 2011;10(2):157-65.

26. bazresikar.mcls.gov.ir [homepage on the Internt]. Tehran: Part Two: Hard and harmful businesses. Jul 30, 2018; Available from: https://bazresikar. mcls.gov.ir/fa/question/hardwork

27. Cheng BS, Chou LF, Farh JL. A triad model of paternalistic leadership: its constructs and measurement. Indigenous Psychological Research in Chinese Societies. 2000;14:3-64.

28. Schwarzer R, Jerusalem M. Generalized self-efficacy scale. In: Weinman, J., Wright, S., Johnston, M. (Eds.), Measures in Health Psychology: A User's Portfolio. Causal and Control Beliefs. NFER-NELSON, Windsor, UK. 1995:35-37.

29. Neal A, Griffin MA. A study of the lagged relationships among safety climate, safety motivation, safety behavior, and accidents at the individual and group levels. Journal of Applied Psychology. 2006; 91(4):946-953. 